\title{
The Need for an Integrated Disaster Risk Reduction \\ Management Strategy in North African Cities: A Case \\ Study of Urban Vulnerability in Algiers (Algeria)
}

\author{
Djillali Benouar
}

\section{Introduction}

For the North African countries, geological, environmental and technological hazards constitute a constant threat to human life and property, sometimes causing major economic losses and disruption. The rapid urbanization, development of critical engineering works such as dams, decaying building stock, implementation of various industries within and around the main cities, industrialization of cities with modern types of buildings and the large concentration of populations, with a heavy dependency on infrastructure and services, living in large cities and/or settling in hazardous areas, are matters of growing concern, as they contribute to heavier loss of life and seriously increasing the economic losses in future disaster damage. The environmental concerns and an increased official and public awareness of various hazards have, in the last decade, led to a rapid rise of interest in hazard and risk evaluations and thus in disaster risk management.

In fact, there are various reasons for investigating the Mediterranean Africa as a unit and for evaluating the various hazards of the entire zone under similar criteria:

(1) In terms of geological process: The countries limiting the southern part of the Mediterranean Sea and its adjacent continuation in the Atlantic Ocean have had, since hundred million years ago, the same tectonic process marked by a relative motion alternating between left and right lateral along the borders of the African and Eurasian plates;

(2) Similar present levels of development: the actual state of development in the whole zone is dominated by a rapid urbanization, high density of population in most important cities and degradation of the environment; 
(3) At the present pace and patterns of rural-to-urban migration and unplanned urbanization are causing increased population densities in urban centres, such areas are a prime reason for increasing vulnerability;

(4) Similar historical developments: the historical developments of the countries in the region shows many common factors, such as cultural background. Similarities in population settlements, building stock characteristics and socio-economic and demographic conditions, various types of pollution, and climate, are very important parameters in the whole process of disaster risk studies in most cities in the zone under consideration. For all these reasons, this research work is concentrated on the city of Algiers, which presents a general case of most of the geological, environmental and technological threats found in all the main cities across the Mediterranean Africa.

Algiers, the Capital of Algeria, including its surroundings communities, with a population of approximately three million, represents the most important concentration of investment, government institutions and population in the whole country. It is the intellectual, social, political and economic centre of the country. In recent years the disaster risks have increased due to overcrowding, faulty land use planning and construction, inadequate infrastructure and services, and environmental degradation and technological plants within and surrounding the city. In the last two decades, the city of Algiers and its surroundings have known an important development in the urban domain as well as in the industrial one and thus it is actually confronted to rapid environmental degradation and to a multiform pollution. The industrial sector implemented within the city itself and its surroundings considerably increase the risk of disasters. Algiers is seriously confronted by risks such as earthquakes, floods, landslides, as well as industrial pollution (four industrial zones), atmospheric pollution (road traffic, main industries, Public dump Oued Smar), solid wastes pollution (Public dump Oued Smar, units for wastes treatment), hydro pollution (superficial and underground water), marine pollution, soil pollution, forests and green spaces degradation, as well as to geological risks. The topography, the waterfront location and the ancient neighbourhoods (Casbah), makes it difficult to affect radical solutions to most of its problems. Decision-makers need adequate integrated information on the likely (probabilities) intensity of these hazards the city will face if it is to reduce vulnerability to disasters. This research work shows the need of integrated disaster risk management in megacities. 


\section{Industrial Pollution}

The industrial activity constitutes a most significant source of pollution and harmful effect to the city of Algiers. It is the origin of several forms of pollution such as hydrous and atmospheric pollution. It is also generating dangerous and toxic wastes posing serious problems for the health of the people as well as their elimination.

From the point of view of the industrial activity, Great Algiers represents one of the most significant areas of the country. The total number of industrial units is approximately 735 public and private in the Wilaya (province) of Algiers, that is to say $7.2 \%$ of the national total estimated at 10200 units, of which 5242 would be located on the coast.

The polluting industrial activity is localized within the periphery of Algiers, mainly in the East at the industrial zones of Gué de Constantine ( $8 \mathrm{~km}$ of the center town), of El Harrach (11 km of the center), Oued Smar (15 km) and Rouiba - Réghaia (27 Km).

The most polluting units on the level of Algiers are:

- Paper mills,

- Manufacture of batteries,

- Oils and soaps,

- Yeasts, detergents, metals heavy,

- Pharmaceutical products,

- Fertilizers, and

- Petroleum products such as gas, gasoline and asphalt.

\section{Air pollution}

The principal sources of pollution in Algiers are:

- Very and intense road traffic,

- Rejections of pollutants by the industrial units established in urban fabric and by the various industrial zones, and

- The combustion of the wastes at the public dump of Oued Smar. 


\section{Road traffic}

The total number of automobiles in Algiers counts approximately 560000 vehicles of all categories (with a daily traffic of 1500 to 2000 vehicles/hour), which represents a quarter of all automobiles in Algeria. This pollution consists of approximately $15 \%$ Co2 , $70 \%$ of $\mathrm{CO}, 40$ to $50 \%$ of $\mathrm{NO}, 30 \%$ of the hydrocarbon none burnt residues, $5 \%$ of $\mathrm{SO} 2$, and the remainder of black fume, dust, and lead.

A quantity of 180 tons lead per year is emitted in the streets of the capital at a rate of $0.5 \mathrm{~g}$ of lead/liter of gasoline for the vehicles, that is to say an annual average of $3.8 \mathrm{mg} / \mathrm{m}^{3}$ (this average is higher than that of the capitals of other countries). The annual average recommended by the World Health Organization (WHO), as a standard of quality of the air not to be exceeded, ranges between 0.5 and $1 \mathrm{mg} / \mathrm{m}^{3}$. Whereas lead concentration in the agglomeration of Algiers east is $2.01 \mathrm{mg} / \mathrm{m}^{3}$ (Aoudia, 1996).

\section{The main industries}

The most polluting industries are:

- The cement factory of Rais Hamidou which emits cement dust charged with combustion gas $\mathrm{NO}, \mathrm{CO} 2$ and of $\mathrm{CO}$, at 30 tons of dust/day (the standard ranges between 15 to 250 tons $/ \mathrm{Km}^{2} /$ year) (Service environment and forests, 1990). This cement factory, localized within the heart of an urban zone (10 km to the west of the center of Algiers), unquestionably constitutes a significant harmful effect to the population and the whole environment in the vicinity. Producing 750 tons of cement per day, this cement factory emits fine particles, made up mainly by products limestone, which causes respiratory diseases. The most visible impact is certainly the deposit of cement dust on the roofs, the vegetation and on the entire zone close to the cement factory. The threshold of $1000 \mathrm{~g}$ of dust $/ 100 \mathrm{~m}^{2} /$ month, determined by a model of dispersion as a norm, is largely exceeded by a radius of $3 \mathrm{~km}$ (INGECO, 1997).

- The tobacco production units of Bab El Oued and El Hamma (both located within the center of Algiers) emit harmful fumes due to the use of fuel.

- The unit of cable-making of Oued Smar emits dust charged with lead, 
- The industrial unit of the greasy substances in the harbor of Algiers emits fume with nauseous odors.

- The manufacturing plant of batteries of Oued Smar emits lead oxide dust.

- The manufacturing plant of painting within Oued Smar emits gas dust charged with asbestos and lead.

- The refinery of Baraki (12 km from the center of Algiers) releases various hydrocarbon gases.

\section{Public dump of Oued Smar}

Solid waste of the Wilaya of Algiers as well as the waste of the industrial zones is send to the public dump of Oued Smar. The initial surface of the dump was 10 hectares but has now reached 37.5 hectares. It is located 13 kilometers from the center of Algiers on clay ground. This public damp reached a very advanced degree of saturation where the monticules of stored waste exceed 6 meters above ground level. An investigation of an engineering and design company (Kaoula, 1996) estimated the quantity of waste which arrives on the discharge including 1600 tons/day of domestic waste at 4000 tons/day, that is to say approximately 1000000 tons/year coming from Wilayates of Algiers, Boumerdes and Tipaza.

The dump further releases nauseous fumes, odors and gas emissions $(\mathrm{CH} 4, \mathrm{CO} 2$, $\mathrm{NH} 3$ ) from the combustion of the household refuse of the city of Algiers, its surroundings and the industrial zones. This pollution is visible at Oued Smar, El Harrach, Bab Ezzouar, Hamiz, Dar El Beida and Eucalyptus.

\section{Pollution by solid waste}

Solid urban wastes can be defined as the whole of the solid waste generated by the urban activity. In Algeria, in particular in Algiers, household refuses pose serious difficulties to the public services to collect them correctly, as they encumber the streets of Algiers and its surroundings. Wild waste dumps on which the inhabitants come to deposit their waste without paying any attention to the impact on the environment. The estimate of the quantity of the waste generated by the agglomeration of Algiers is about 1408 tons per day (ANAT, 1996). The quantity of 2 500 tons per day is produced on the whole of Wilaya of Algiers, that is to say 910000 tons/year. Studies estimated that this quantity will pass 3200 tons/day in 2005 already. 
Industrial facilities dump more than 2000 tons of uncontrolled waste daily, particularly asbestos, acid, cyanide, phosphorus, etc. It should also be noted that waste of slaughterhouses is also dumped directly on the public dump of Oued Smar leading to various health problems.

The nature of solid waste in Algiers is:

- Domestic waste: 657000 tons/year;

- Industrial waste: 930000 tons/year;

- Waste of the administrations (paper, paperboards, etc.) : 90000 tons/year;

- Waste of the markets: 50000 tons/year;

- Waste of hospital (syringes, bandages, etc.) : 3900 tons/year;

- Waste of trade: 80000 tons/year;

- Apecial waste (toxic): 30000 tons/year;

(Service CPVA in Inspection of environment of Algiers).

\section{Hydrous pollution}

Hydrous pollution relates to the disposal of liquid and solid wastes in the ground. Pollution today reaches most of the hydrographic networks and poses serious problems for water resources and contributes to the degradation of the living conditions in the aquatic environment.

\section{Superficial waters}

The superficial water pollution is caused mainly by the deterioration and lack of maintenance of sewage systems causing effluents to be dispersed into rivers. Sewage water of the city of Algiers and that of all the other communes of the Wilaya is discharged to the sea, either directly, or by the means of Oued El Harrach. The total volume of the wastewater poured in the Oued El Harrach is approximately 57 $000 \mathrm{~m}^{3} /$ day (IEA, 1997).

\section{Underground waters}

The water table of the plain of Mitidja constitutes the main water tank of the area. It is prone to many contaminations:

- Pesticides, nitrate fertilizers;

- the liquid infiltrations of the water table;

- Nitrates of the catchments basin of Oued El Harrach. 
The pollution of the water tables by hydrocarbons is a serious problem since it can expand to surrounding collecting fields. Indeed, drillings of the water table of Algiers were subjected to pollution by hydrocarbons. Most of the drillings analyzed present a very high degree of pollution, showing a largely higher index than the maximum permissible concentration (10mg/litre) for the water intended for human consumption (Bruchet, 1985).

The discharge of domestic and industrial waste water without treatment in the receiving medium constituted by a hydrographic network which is characterized by nonpermanent rivers and relatively low flow not allowing a process of self purification, dangerously threatens the water table, the beaches, the dams as well as the public health.

\section{Marine pollution}

The bay of Algiers covers a water area of 184 ha, characterized by pollution of urban and industrial origin. Most of the cities in the Wilaya and industrial facilities established on the of Algiers littoral pour their waste water either directly into the sea, or by the means of the Oueds, without preliminary processing which causes the deterioration the sea water quality. At the Algiers harbor, 25 outlets of urban and industrial waste water were listed, with presence of oils and greases coming from the harbor maintenance workshops, the sewage waters of Hamma, the hospital Mustapha Bacha, the factories of the fatty corps, the pasta production unit, oil company and electricity production unit in addition to the draining operated by the tankers and other ships either within the harbor or at large (Urbanis, 1998).

\section{Soils Pollution}

The pollution of the soil may have its origin from the industrial activities. The massive use of the artificial fertilizers, the use of certain organic soil conditioners and the systematic use to the pesticides result in a very significant increase in the agricultural outputs; unfortunately this rise of the productivity of the grounds is often accompanied by the increase in the contents of heavy metals in these grounds. Indeed, the contamination of the grounds by heavy metals constitutes a phenomenon which results mainly from the various human activities such as the agricultural use of fertilizers (phosphates, fertilizers, organic soil conditioners, etc) and the industrial wastes. The analysis carried out in various places of the Mitidja plain shows a content of nitrates between 50 and $250 \mathrm{mg} / \mathrm{l}$, whereas the standard set by WHO is 45 mg/l (ANAT, 1996). 


\section{Deterioration of the forests (Deforestation)}

The forests of Wilaya of Algiers are in an advanced state of deterioration. These forests cover a surface of 633 ha for a total surface of 5338 ha.

The principal causes of deterioration of the forests are:

- Attack of insects;

- Fires;

- Atmospheric pollution of origin generated by the industrial activity; case of the cement factory of Rais Hamidou which devastated the forest of Bainem;

- Neglect of the sector of the forests in the land use decisions;

- Anarchistic urbanization; and

- Proliferations of the cities.

\section{Floods}

Rapid urbanization is a major factor in the increase of floods. Flash floods is a growing concern due to urban runoff, the decline of open spaces, engineering works that divert river flows and weak city drainage systems (neglect, lack of maintenance). Inappropriate housing on river banks or near delta is a major concern.

The last Algiers flood and mudflow on 10 November 2001 caused the loss of 712 human lives, injured 350, 116 were missing, and 1800 housing units and 56 schools suffered damage, and scores of bridges, roads, public works were damaged. $1000000 \mathrm{~m} 3$ (up to $10 \mathrm{~m}$ thick) of mud were dispersed in the streets of Bab el Oued, were more than 350 vehicles (cars, trucks and buses) with passengers were buried under mud. The preliminary estimated damage was US\$250000 000.

\section{Landslides}

Landslides have occurred with or without the help of earthquakes. During the last Algiers flood and mudflow of 10 November 2001, several landslide cases were recorded within Algiers and its surroundings. Rocks and soil sliding rapidly downhill. 


\section{Earthquakes}

Algiers as a densely built, densely populated city located on seismic zone is prone to earthquakes. The city suffered several damaging earthquakes in the past, occurring within the city or in adjacent areas. The earthquake catalogue for the Wilaya of Algiers dates back to 1365 . The building stock of the capital Algiers presents a high vulnerability to earthquake loads and thus seismic risk management is really needed if the government wants to avoid disasters.

\section{Conclusions and Recommendations}

Decision-makers need adequate integrated information on the likely (probabilities) intensity of the disaster the city will face if they are to reduce disaster vulnerability. This research shows the need of integrated disaster risk management in megacities such as Algiers.

In a country which, regrettably, is as disaster-prone as Algeria, it is of crucial importance, at the macro-level, for the country to have a well established and well regulated disaster risk management plan. This will enable the government to avoid undue crisis management when future emergencies occur. It is also of crucial importance, again at the macro-level, to integrate disaster management in all its facets with government's mainstream policies and plans for national development.

Disaster risk management and economic development are not two separate disciplines that compete for resources. They are synonymous and their funding should be a combined administrative process.

To fulfil these goals, the research proposed the establishment of a national disaster research and management agency in Algeria. This agency has two objectives (1) to prepare the national disaster management plan and (2) to create a sustainable cadre of disaster management staff at all levels, and to promote institutional and public awareness of disasters, their effects and likely relief activities.

The need of permanently established national disaster management organisation is a must today. The organisation chart describes the structure, the chain of control and reporting, and the main working relationships (see Figure1 below). It allows having a permanently established and functioning integrated data collection system to gather information relevant to disaster management in all its aspects. 
However, it has a wider application and provides an important step forward towards an effective national data collection system, and this will require extensive research work. Several partial data bases are already available and these will be drawn upon in the creation of the agency which will attempt to provide a more general view within a single framework. The structure of the agency will then incorporate existing government, non-government and community information/data sources in order to provide an overall picture of potential danger zones, multi-sectoral early warning indicators and available resources. This enables particular attention to be paid to problem geographic sectors or problem functions, and the consequent mobilisation and allnoation nf racou urnoc in nroventing disasters.

\section{Proposed Structure of NDRMA in}

\section{Algeria}

\section{Cabinet of the Prine Minister}

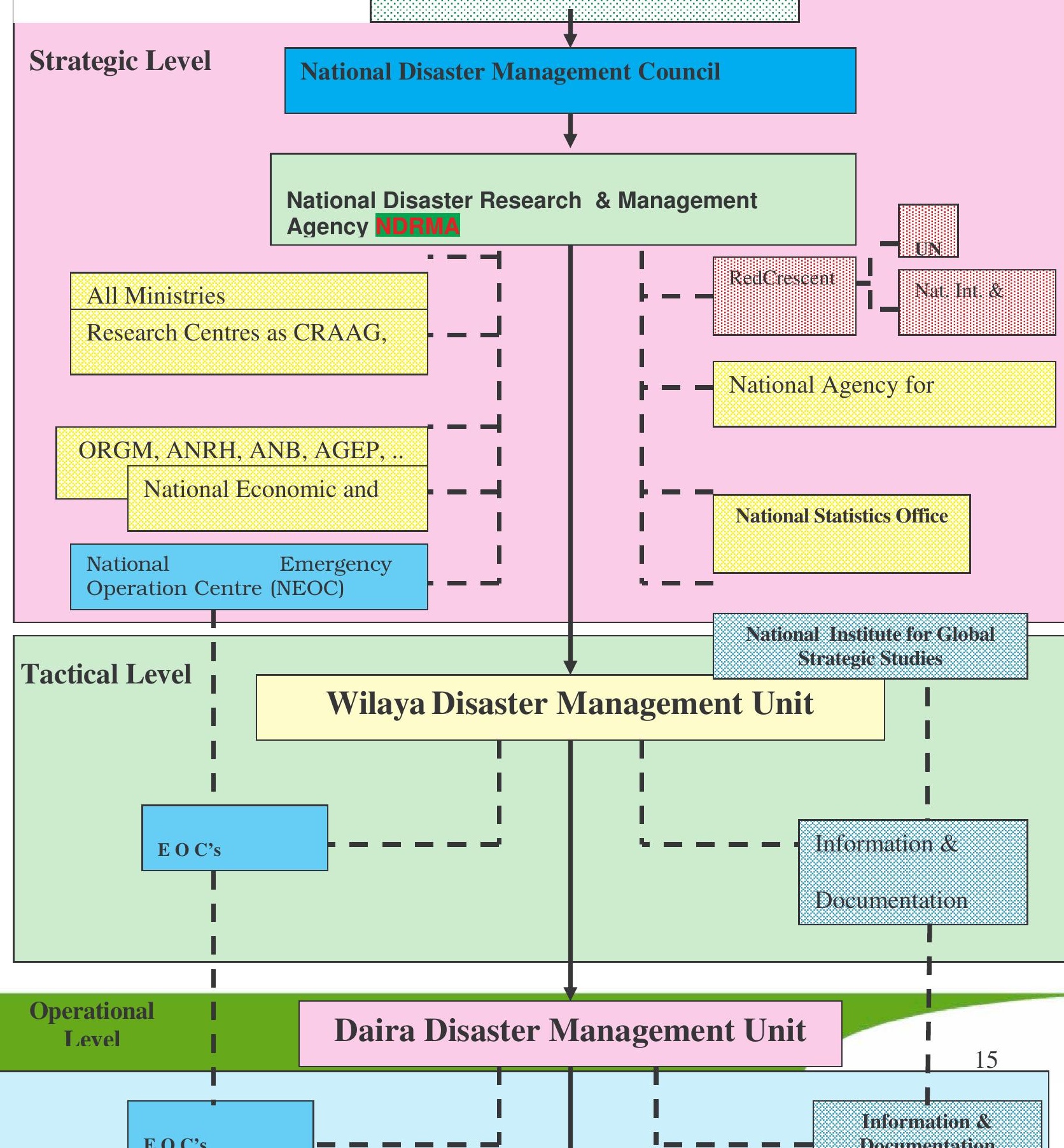




\section{References}

ABDELOUAHEB, N. AND T. SADOUN (1996): Evaluation de la pollution de l'eau par les métaux lourds à l'aide des moules de la région d'Alger, in communications $1^{\mathrm{er}}$ Séminaire Maghrebin sur l'eau, Université de Tizi Ouzou (Algérie), Juin.

\section{ANAT (AGENCE NATIONALE D'AMÉNAGEMENT DU TERRITOIRE) (1996) :}

Schéma d'organisation de l'armature urbaine de la région métropolitaine d'Alger.

AOUDIA, T. (1991) : Pollution atmosphérique dans la région Est d'Alger, in Etudes : Estimation des concentrations dans l'air à l'aide d'un modèle de boite ; CERHYD, Alger.

BENTIR, M. (1995) : La problématique des déchets solides en Algérie ; Revue EECEdil.

BRUCHET, A. (1985): Recherche d'hydrocarbures dans les forages de la nappe d'Alger ; Rapport Lyonnaise des Eaux, Laboratoire Central, France.

DVAHA (1990): Dossier Pollution et nuisances de la Wilaya d'Alger ; Division du développement des activités hydrauliques et agricoles, Service Environnement des forêts de la Wilaya d 'Alger , 241 pages.

IEA (1997) : Rapport sur l'état environnementale ; Inspection de l'Environnement de la Wilaya d'Alger.

INGECO (1997) : Audit environnemental de la cimenterie de Rais Hamidou (Rapport préliminaire).

KAOULA. A. (1996) : Alger, une capitale malade de ses ordures; Revue Symbiose, 34p).

MELHA, A. (2001) : Les enjeux environnementaux en Algérie, Pifp, June, Alger.

Programme du Gouvernement algérien pour l'an 2000. 
REVUES : « Algérie - Environnement », No. 1 and 2, 1998 and 1999.

ROUIDI. L.1995) : Les déchets solides urbains du Grand Alger; Revue Edil - Info. Quantification, Caractérisation et propositions techniques pour leur élimination.

SELLALI. B. (1995) : Influence des rejets urbain et industriels sur l'environnement du littoral: Quelques exemples en Algérie; p.69. AGEP: Actes de la Conférence Nationale sur la Nouvelle Politique de l'Eau.

URBANIS (1998): Problèmes environnementaux dans le Gouvernorat du Grand Alger. 